
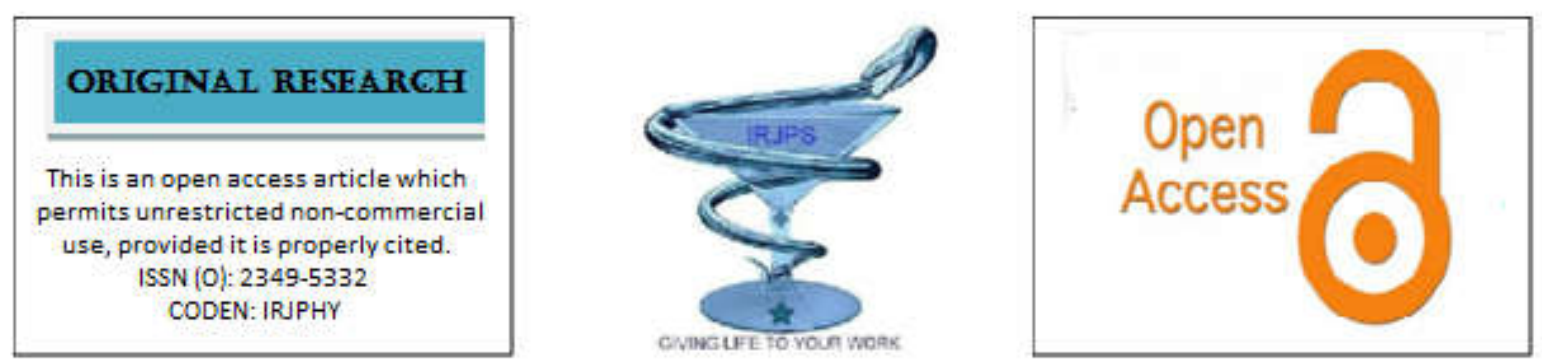

\title{
EVALUATION OF REPRODUCTIVE HORMONES AND THEIR IMPACTS ON THE NUMBER OF OOCYTES AND EMBRYOS AMONG WOMEN TREATED FOR IVF LONG PROTOCOLS IN PRINCE RASHID HOSPITAL, JORDAN
}

\author{
Mothanna Nazmi Jaber Nawafleh, Raed Aref Mousa Sharadgah, Mohammed Fayez Bataineh, Alaa Abdullah \\ Al Sharman, Shirin Mahmmoud Imbark Alawadi \\ Royal Medical Services, Prince Rashid Hospital, Jordan
}

Submitted on: 20.04.19;

Revised on: 04.05.19;

Accepted on: 14.05.19

\begin{abstract}
:
Introduction: IVF protocols can be short or long. There are indications for any of them to be followed. This can depend on the clinical status of infertility of a woman.

Study objectives:The study purposes to evaluate reproductive hormones and their impacts on both the number of oocytes and embryos among women treated for IVF-long protocols in Prince Rashid Hospital, Jordan.

Methods and patients: A retrospective design was conducted to collect data from files of patients under treatment with IVF-long protocols. A total of 113 files of women who underwent for this treatment were included in this study. Study variables included demographic variables including age, hormone levels of FSH, and LH, the number of oocytes, and embryos, and the result of IVF.

Study results: The most important findings showed that the success rate was $51.3 \%$ following long IVF protocols. Age did not impact study variables. Both of oocyte number, and embryo number impacted significantly the result of pregnancy. Correlations, significantly and positively, were found between LH and oocyte number, oocyte number and embryo number, oocyte number and pregnancy result, and embryo number with pregnancy results.

Conclusion: The present study showed that the success rate of pregnancy using long protocols for IVF was $51.3 \%$. The pregnancy result depended on both oocyte number and embryo number. LH correlated with oocyte number.
\end{abstract}

KEYWORDS: IVF, Long protocol, LH, FSH, Oocyte number, Embryo number

Corresponding author: M. N. J. Nawafleh

E-mail: nmothanna@yahoo.com
Indian Research Journal of Pharmacy and Science; 20(2019) 1832-1837;

Journal Home Page: https://www.irjps.in

DOI: 10.21276/irjps.2019.6.1.9 


\section{INTRODUCTION:}

Infertility is considered a major medical problem due to genetic factors, a matter that led to continuous research conduction in the field of assisted reproductive technology (ART) ${ }^{1}$.

Nowadays, what is called "assisted reproductive technology" (ART) is considered a very efficient therapeutic approach for infertility. This approach is a trial to obtain a large number of oocytes with good quality through the use of the technique of controlled ovarian hyper-stimulation $(\mathrm{COH})$ to increase the probabilities of success in vitro fertilization (IVF) $)^{2-4}$.

Recently, it has been shown that using long protocols with the gonadotropin-releasing hormone $(\mathrm{GnRH})$ analog in addition to gonadotropins for $\mathrm{COH}$, these protocols have been well established ${ }^{5}$.

Long protocol strategies involve the use of approaches of superovulation with the use of GnRHand HMG or FSH ${ }^{6,7}$. (Hazoutet al., 1993; Loutradis et al., 2005). The idea of using the long protocol is to generate a status of hypogonadotropichypogonadism. It has been reported that the use of long protocols led to high pregnancy rates $^{8}$. Long protocols depend on the use of GnRH agonist. The idea of these approaches that such analogues include the existence of some amino acids substitutions that increases the stability of analogues in comparison with natural hormones ${ }^{8-10}$. GnRH agonists permit continuous induction of gonadotropin secretion, and GnRH antagonists work asmediators for hypophysectomy ${ }^{11}$.

Study objectives:The study purposes to evaluate reproductive hormones and their impacts on both the number of oocytes and embryos among women treated for IVF-long protocols in Prince Rashid Hospital, Jordan.

\section{METHODS AND PATIENTS:}

Study design: A retrospective design was conducted to collect data from files of patients under treatment with IVF-long protocols.

Study sample: A total of 113 files of women who underwent for this treatment were included in this study. Files with complete information were analyzed.

Study variables: Study variables included demographic variables such as age, hormone levels of $\mathrm{FSH}$, and $\mathrm{LH}$, the number of oocytes, and embryos, and the result of IVF.

Statistical analysis: An excel sheet was used to enter the data for all included files. The data were further analyzed using SPSS version 21. Data were presented as means and standard deviations. The effect of hormone levels on the number of oocytes and embryos was computed using One Way Anova, and Pearson correlation was used to compute the correlation between study variables. The significance was considered at $p \leq 0.05$.

\section{RESULTS:}

\section{General characteristics of study participants}

As shown in table 1, the mean age of study participants was $27.35 \pm 4.17$ years. The mean level of FSH was $6 \pm 1.99 \mathrm{IU} / \mathrm{L}$, and of LH was $5.44 \pm 3.65$ IU/L. The mean number of oocytes was $3.48 \pm 4.46$, while the mean number of embryo was $4.08 \pm 2.10$. The pregnancy success rate was $51.3 \%$.

Table 1: General characteristics of study participants

\begin{tabular}{|c|c|}
\hline Variable & Description \\
\hline Age $(\mathrm{M} \pm \mathrm{SD})$ years & $27.35 \pm 4.17$ \\
\hline FSH $(\mathbf{M} \pm$ SD) IU/L & $6 \pm 1.99$ \\
\hline LH $(\mathrm{M} \pm \mathrm{SD}) \mathrm{IU} / \mathrm{L}$ & $5.44 \pm 3.65$ \\
\hline Oocyte No $(\mathbf{M} \pm$ SD $)$ & $13.48 \pm 4.46$ \\
\hline Embryo No $(M \pm S D)$ & $4.08 \pm 2.10$ \\
\hline $\begin{aligned} \text { Pregnancy result }(\mathbf{N}, \%): \\
-\quad \text { Pregnancy } \\
-\quad \text { No pregnancy }\end{aligned}$ & $\begin{array}{l}58(51.3 \%) \\
55(48.7 \%)\end{array}$ \\
\hline
\end{tabular}


The impact of age on study variables

As shown in table 2, the impact of age on study variables was examined by One Way Anova. The results did not reveal any significant association between variables $(\mathrm{p}>0.05)$.

Table 2: The impact of age on study variables

\begin{tabular}{|c|c|c|c|c|c|c|}
\hline & & $\begin{array}{l}\text { Sum of } \\
\text { Squares }\end{array}$ & df & $\begin{array}{c}\text { Mean } \\
\text { Square }\end{array}$ & $\mathbf{F}$ & Sig. \\
\hline \multirow[t]{3}{*}{ FSH } & $\begin{array}{l}\text { Between } \\
\text { Groups }\end{array}$ & 76.078 & 21 & 3.623 & .901 & .590 \\
\hline & Within Groups & 361.924 & 90 & 4.021 & & \\
\hline & Total & 438.002 & 111 & & & \\
\hline \multirow[t]{3}{*}{$\mathbf{L H}$} & $\begin{array}{l}\text { Between } \\
\text { Groups }\end{array}$ & 164.172 & 21 & 7.818 & .530 & .950 \\
\hline & Within Groups & 1253.660 & 85 & 14.749 & & \\
\hline & Total & 1417.832 & 106 & & & \\
\hline \multirow[t]{3}{*}{ Oocyte NO } & $\begin{array}{l}\text { Between } \\
\text { Groups }\end{array}$ & 525.064 & 21 & 25.003 & 1.339 & .173 \\
\hline & Within Groups & 1680.900 & 90 & 18.677 & & \\
\hline & Total & 2205.964 & 111 & & & \\
\hline \multirow[t]{3}{*}{$\begin{array}{l}\text { Embryo } \\
\text { NO }\end{array}$} & $\begin{array}{l}\text { Between } \\
\text { Groups }\end{array}$ & 74.749 & 21 & 3.559 & .764 & .755 \\
\hline & Within Groups & 419.528 & 90 & 4.661 & & \\
\hline & Total & 494.277 & 111 & & & \\
\hline \multirow[t]{3}{*}{ Result } & $\begin{array}{l}\text { Between } \\
\text { Groups }\end{array}$ & 6.700 & 21 & .319 & 1.349 & .167 \\
\hline & Within Groups & 21.291 & 90 & .237 & & \\
\hline & Total & 27.991 & 111 & & & \\
\hline
\end{tabular}

The impact of study variables on pregnancy results

We examined the impact of study variables on the pregnancy results by One Way Anova test. The results showed that two variables significantly impacted the pregnancy results, the oocyte number $(p=0.000)$, and embryo number $(p=0.000)($ table 3$)$.

Table 3: The impact of study variables on pregnancy results

\begin{tabular}{|c|c|c|c|c|c|c|}
\hline & & $\begin{array}{c}\text { Sum of } \\
\text { Squares }\end{array}$ & df & $\begin{array}{c}\text { Mean } \\
\text { Square }\end{array}$ & $\mathbf{F}$ & Sig. \\
\hline \multirow[t]{3}{*}{ FSH } & $\begin{array}{l}\text { Between } \\
\text { Groups }\end{array}$ & 3.948 & 1 & 3.948 & .991 & .322 \\
\hline & Within Groups & 442.010 & 111 & 3.982 & & \\
\hline & Total & 445.958 & 112 & & & \\
\hline \multirow[t]{3}{*}{ LH } & $\begin{array}{l}\text { Between } \\
\text { Groups }\end{array}$ & 2.673 & 1 & 2.673 & .200 & .656 \\
\hline & Within Groups & 1419.383 & 106 & 13.390 & & \\
\hline & Total & 1422.056 & 107 & & & \\
\hline OocyteNO & Between & 415.346 & 1 & 415.346 & 25.460 & .000 \\
\hline
\end{tabular}




\begin{tabular}{|c|c|c|c|c|c|c|}
\hline & Groups & & & & & \\
\hline & Within Groups & 1810.849 & 111 & 16.314 & & \\
\hline & Total & 2226.195 & 112 & & & \\
\hline \multirow[t]{3}{*}{$\begin{array}{l}\text { EmbryoN } \\
\text { O }\end{array}$} & $\begin{array}{l}\text { Between } \\
\text { Groups }\end{array}$ & 60.657 & 1 & 60.657 & 15.527 & .000 \\
\hline & Within Groups & 433.626 & 111 & 3.907 & & \\
\hline & Total & 494.283 & 112 & & & \\
\hline \multirow[t]{3}{*}{ Age } & $\begin{array}{l}\text { Between } \\
\text { Groups }\end{array}$ & 38.548 & 1 & 38.548 & 2.240 & .137 \\
\hline & Within Groups & 1892.871 & 110 & 17.208 & & \\
\hline & Total & 1931.420 & 111 & & & \\
\hline
\end{tabular}

Correlation between study variables

As shown in table 4, we examined the correlation between study variables by Pearson correlation. LH was positively and significantly correlated with oocyte number $(\mathrm{r}=0.290, \mathrm{p}=0.030)$. Oocyte number was positively and significantly correlated with embryo number $(\mathrm{r}=0.654, \mathrm{p}=0.000)$, and pregnancy result $(\mathrm{r}=0.432, \mathrm{p}=0.000)$. Embryo number was also correlated significantly and positively with pregnancy results $(r=0.350, p=0.000)$.

Table 4: Correlation between study variables

\begin{tabular}{|c|c|c|c|c|c|c|c|}
\hline & & Age & FSH & LH & $\begin{array}{c}\text { Oocyte } \\
\text { NO }\end{array}$ & $\begin{array}{c}\text { Embryo } \\
\text { NO }\end{array}$ & Result \\
\hline \multirow[t]{3}{*}{ Age } & $\begin{array}{l}\text { Pearson } \\
\text { Correlation }\end{array}$ & 1 & $-.098-$ & $-.185-$ & $-.035-$ & .003 & $-.141-$ \\
\hline & Sig. (2-tailed) & & .302 & .056 & .710 & .976 & .137 \\
\hline & $\mathbf{N}$ & 112 & 112 & 107 & 112 & 112 & 112 \\
\hline \multirow[t]{3}{*}{ FSH } & $\begin{array}{l}\text { Pearson } \\
\text { Correlation }\end{array}$ & $-.098-$ & 1 & .133 & $-.140-$ & $-.152-$ & $-.094-$ \\
\hline & Sig. (2-tailed) & .302 & & .171 & .140 & .108 & .322 \\
\hline & $\mathbf{N}$ & 112 & 113 & 108 & 113 & 113 & 113 \\
\hline \multirow[t]{3}{*}{ LH } & $\begin{array}{l}\text { Pearson } \\
\text { Correlation }\end{array}$ & $-.185-$ & .133 & 1 & $.209^{*}$ & .116 & $-.043-$ \\
\hline & Sig. (2-tailed) & .056 & .171 & & .030 & .231 & .656 \\
\hline & $\mathbf{N}$ & 107 & 108 & 108 & 108 & 108 & 108 \\
\hline \multirow[t]{3}{*}{ Oocyte NO } & $\begin{array}{l}\text { Pearson } \\
\text { Correlation }\end{array}$ & $-.035-$ & $-.140-$ & $.209^{*}$ & 1 & $.654^{* *}$ & $.432^{* *}$ \\
\hline & Sig. (2-tailed) & .710 & .140 & .030 & & .000 & .000 \\
\hline & $\mathbf{N}$ & 112 & 113 & 108 & 113 & 113 & 113 \\
\hline \multirow[t]{3}{*}{ Embry NO } & $\begin{array}{l}\text { Pearson } \\
\text { Correlation }\end{array}$ & .003 & $-.152-$ & .116 & $.654^{* *}$ & 1 & $.350^{* * *}$ \\
\hline & Sig. (2-tailed) & .976 & .108 & .231 & .000 & & .000 \\
\hline & $\mathbf{N}$ & 112 & 113 & 108 & 113 & 113 & 113 \\
\hline \multirow[t]{3}{*}{ Result } & $\begin{array}{l}\text { Pearson } \\
\text { Correlation }\end{array}$ & $-.141-$ & $-.094-$ & $-.043-$ & $.432^{* *}$ & $.350 *$ & 1 \\
\hline & Sig. (2-tailed) & .137 & .322 & .656 & .000 & .000 & \\
\hline & $\mathbf{N}$ & 112 & 113 & 108 & 113 & 113 & 113 \\
\hline
\end{tabular}




\section{DISCUSSION:}

The present study showed that the success rate of pregnancy test following long protocols was $51.3 \%$. Long protocols usually give high success rates. This finding is in agreement with previous studies ${ }^{4,12}$. This is expected to due to follow long protocol which generates large number of oocytes.

The results of the present study did not reveal any significant association between age and study variables. This is clearly implies that the success rate of pregnancy was independent of age. This is not in agreement with other studies that clearly concluded that age was a very important key factor in success of pregnancy $^{12-14}$.

The results of this study showed that the pregnancy result depended on oocyte number $(\mathrm{p}=0.000)$, and embryo number $(\mathrm{p}=0.000)$. We think that these findings are plausible and expected. However previous studies reported similar findings ${ }^{12,15,16}$.

\section{REFERENCES:}

1- DeekshyaShrestha, Xiaolin La, Huai L. Feng. Comparison of different stimulation protocols used in in vitrofertilization: a review. Ann Transl Med, 2015, 3(10):137.

2- Kamel RM. Assisted reproductive technology after the birth of louise brown. J ReprodInfertil., 2013, 14:96-109.

3- Alaee S, Novin MG, Noroozian M, Yeganeh F, Pakravesh J, Heidari M, et al. Evaluation of progesterone receptor, FKBP51 and FKBP52, associated with uterine receptivity, in endometrial tissue of women with repeated implantation failure. ActaEndocrinologica (Buc)., 2014, 10:32939.

4- Parsanezhad ME, NamavarJahromi B, Rezaee S, Kooshesh L, Alaee S. The Effect of Four Different Gonadotropin Protocols on Oocyte and Embryo Quality and Pregnancy Outcomes in IVF/ICSI Cycles; A Randomized Controlled Trial. Iran J Med Sci, 2017,42 (1): 57-65.
Correlation studies showed that oocyte number was significantly and positively correlated with $\mathrm{LH}$ $(\mathrm{r}=0.290, \mathrm{p}=0.030)$, embryo number $(\mathrm{r}=0.654$, $\mathrm{p}=0.000)$, and pregnancy result $(\mathrm{r}=0.432, \mathrm{p}=0.000)$. It seems that obtaining a good number of oocytes with good quality is a principal step to have success pregnancy. These findings confirm previous studies that reported similar findings ${ }^{17-19}$.

Embryo number was also correlated significantly and positively with pregnancy results $(\mathrm{r}=0.350$, $p=0.000$ ). This finding implies that the more the number of good embryos, the more the success rate of pregnancy. This is in line with other studies ${ }^{19-21}$.

\section{CONCLUSION:}

The present study showed that the success rate of pregnancy using long protocols for IVF was $51.3 \%$. The pregnancy result depended on both oocyte number and embryo number. LH correlated with oocyte number.

5- Turhan N, Pekel A, Ayrim A, Kasap B, BAYRAK Ö. Effectiveness of HP-hMG versus $\mathrm{r}$-FSH in patients undergoing IVF/ ICSI cycles with moderate male-factor infertility. Turk J Med Sci., 2013, 43:144-9.

6- D. Loutradis, K. Stefanidis, P. Drakakis, A. El Sheikh,S. Milingos, A. Antsaklis, S. Michalas. Comparison between "short" and "long" protocolsin an ICSI programme. European Journal of Obstetrics \& Gynecology andReproductive Biology, 2005, 120, 69-72.

7- Hazout A, Ziegler Ade, Comel C, Fernandez N, Lelaidier C, FrydmanR. Comparison of short 7-day and prolonged treatment with gonadotropin releasing hormone agonist desensitization for controlled ovarianhyperstimulation. FertilSteril,1993, 59:596-600.

8- Daya S. Gonadotropin releasing hormone agonist protocols for pituitary desensitization in in vitro fertilization and gamete intrafallopian transfer cycles. Cochrane Database Syst Rev, 2000, 2:CD001299. 
9- Franco JG Jr, Baruffi RL, Mauri AL, et al. $\mathrm{GnRH}$ agonist versus GnRH antagonist in poor ovarian responders: a meta-analysis. Reprod Biomed Online, 2006, 13:618-27.

10- Itskovitz-Eldor J, Kol S, Mannaerts B. Use of a single bolus of GnRH agonist triptorelin to trigger ovulation after $\mathrm{GnRH}$ antagonist ganirelix treatment in women undergoing ovarian stimulation for assisted reproduction, with special reference to the prevention of ovarian hyperstimulation syndrome: preliminary report: short communication. Hum Reprod, 2000, 15:1965-8.

11- Tan SL, Kingsland C, Campbell S, et al. The long protocol ofadministration of gonadotropin releasing hormone agonist is superiorto the short protocol for ovarian stimulation for in vitro fertilization.FertilSteril, 1992, 57:810-4.

12- Maryam Eftekhar, Elham Rahmani, Soheila Pourmasumi1 (2014). Evaluation of clinical factors influencing pregnancy rate in frozen embryo transfer. Iran J Reprod Med, 12 (7): 513-518.

13- Dal Prato L, Borini A, Cattoli M, Bonu MA, Sciajno R, Flamigni C. Endometrial preparation for frozenthawed embryo transfer with or without pretreatment with gonadotropin-releasing hormone agonist. FertilSteril, 2000, 77: 956-960.

14- Salumets A, SuikkariAM, Makinen S, Karro H, RoosA, Tuuri T (2006). Frozen embryo transfers: implications ofclinical and embryological factors on the pregnancyoutcome. Hum Reprod, 21: 23682374.

15- Schalkoff ME, Oskowitz SP, Powers RD. A multifactorial analysis of the pregnancy outcome in a successful embryo cryopreservation program. Fertil Steril, 1993, 59: 1070-1074.
16- Check JH, Choe JK, Nazari A, Fox F, Swenson K. Fresh embryo transfer is more effective than frozen for donor oocyte recipients but not for donors. Hum Reprod, 2001,16: 1403-1408.

17- Huirne JA, van Loenen AC, Schats R, McDonnell J, Hompes PG, Schoemaker J, et al. Dose-finding study of daily GnRH antagonist for the prevention of premature LH surges in IVF/ICSI patients: optimal changes in LH and progesterone for clinical pregnancy. Hum Reprod,2005, 20: 359-367.

18- Raju GA, Chavan R, Deenadayal M, Gunasheela D, Gutgutia R, Haripriya G, et al. Luteinizing hormone and follicle stimulating hormone synergy: A review of role in controlled ovarian hyper-stimulation. J Hum ReprodSci, 2013;6: 227-234.

19- RaffaellaDepalo, Paolo Trerotoli ,Annarosa Chincoli, Margherita Patrizia Vacca, Giuseppina Lamanna, Ettore Cicinelli. Endogenous luteinizing hormone concentration and IVF outcome during ovarian stimulation in fixed versus flexible GnRH antagonist protocols: An RCT.Int J ReprodBioMed,2017, 16 (3): 175-182.

20- Bosch E, Escudero E, Crespo J, Simón C, Remohí J, Pellicer A. Serum luteinizing hormone in patients undergoing ovarian stimulation with gonadotropin-releasing hormone antagonists and recombinant follicle-stimulating hormone and its relationship with cycle outcome. Fertil Steril, 2005, 84: 1529-1532

21- Kolibianakis EM, Albano C, Kahn J, Camus M, Tournaye H, Van Steirteghem AC, et al. Exposure to high levels of luteinizing hormone and estradiol in the early follicular phase of gonadotropin-releasing hormone antagonist cycles is associated with a reduced chance of pregnancy. Fertil Steril, 2003, 79: 873-880. 